2. Abrication of Metal-Ceramic Functionally Graded Materials by Microwave Sintering / Bykov Yu. V., Egorov S. V., Eremeev A. G. etc. // Inorganic Materials: Applied Research. 2012. Vol. 3, Issue 3. P. 261-269.

3. El-Naggar S. M., Mikhaiel A. A. Disinfestation of stored wheat grain and flour using gamma rays and microwave heating // Journal of Stored Products Research, 2011. Vol. 47, Issue 3. P. 191-196.

4. Potentials of Microwave Heating Technology for Select Food Processing Applications - a Brief Overview and Update / Puligundla P., Abdullah S. A., Choi W., Jun S., Oh S. E., Ko S. // Food Process Technolgy. 2013. Vol. 4, Issue 11. P. 2-9.

5. Микроволновая энергия, как фактор интенсификации тепломассопереноса и формирования полиэкстракта / Бурдо О.Г., Сиротюк И.В., Альхури Ю., Левтринская Ю.О. // Problemele energeticii regionale. 2016. Vol.1 (36) P. 59-71.

6. Arun S. Mujumdar. Handbook of Industrial Drying. 4th Edition CRC Press. Taylor Francis Group. 2014. 1348 p.

DOI https://doi.org/10.30525/978-9934-588-79-2-1.43

\title{
ВИКОРИСТАННЯ ВОДОРОДУ \\ ЯК АЛЬТЕРНАТИВНОГО ПАЛИВА ДЛЯ МОРСЬКОГО ФЛОТУ СЬОГОДНІ ТА В МАЙБУТНЬОМУ
}

\author{
Мисько В. О. \\ стариий викладач \\ кафедри суднового машинобудування та енергетики \\ Херсонської філії Національного університету кораблебудування \\ імені адмірала Макарова \\ Авдюнін Р. Ю. \\ викладач кафедри суднового машинобудування та енергетики \\ Херсонської філії Національного університету кораблебудування \\ імені адмірала Макарова \\ м. Херсон, Украӥна
}

197 країн в 1915 році підписали Паризьку угоду по захисту клімату. Глобальне потепління відбувається через підвищення викидів $\mathrm{CO}_{2}$. В доповідях в ООН в 2018 році було приведено кількість викидів 55,3 гігатонн. При таких темпах забруднення довкілля, до кінця століття температура на Землі зможе підвищитися на 3,2 градуси, це повне 
порушення кліматичної рівноваги, та екології. Експерти ООН пропонують перехід транспортних засобів на альтернативні види палив [1].

Температура самозаймання водородно-повітряної суміші становить $536^{\circ} \mathrm{C}$ та вища ніж у вуглеводневих палив, але дякуючи низькій енергії активації $\mathrm{H}_{2}$ для його самозаймання потрібно значно менша кількість енергії. В умовах камери згорання швидкість розповсюдження полум'я значно підвищуватиметься завдяки впливу турбулізації та високого тиску. Великі значення швидкості згорання є наслідком високої жорсткості процесу згорання. Стійке самозаймання $\mathrm{H}_{2}$ можливо забезпечувати $з$ допомогою невеликої дози запального (пілотного) палива, або за допомогою каталізатора $\mathrm{H}_{2}$, який подати зі свіжим зарядом повітря, або впорскуванням в камеру згорання. Температура горіння в факелі $3200^{\circ} \mathrm{C}$. Завдяки широкому концентраційному самозайманню водороду відкривається змога якісного регулювання потужності СДВЗ. Індикаторний ККД буде дещо підвищуватись.

Для виконання вимог Парижської угоди стосовно $\mathrm{CO}_{2}$ та викидів сірки. Використання водороду в морських суднових двигунах потрібно не в сумішах з вуглеводневими паливами, а як самостійне паливо 3 внутрішнім сумішоутворенням.

Для зменшення ступеня стиснення потрібно використовувати іскрозапалювання, або пілотну порцією дизельного палива. Іскрозапалювання потрібно використовувати по принципу газомоторних двигунів. В передкамеру подається водород, іскрозапалюється і виштовхується в камеру згорання - куди подається основна порція водороду відповідно навантаженню на двигун.

Круїзна компанія Royal Caribbean розробляє клас суден, які отримуватимуть енергію від паливних елементів на скрапленому природному газі. Перший паром буде побудовано у 2022 році, який буде використовувати тільки водородне паливо.

В 2021 році будуть проведені спеціальні випробування на базі круїзних суден. Круїзний флот спалює майже 250000 літрів дизельного палива в день сьогодні. По оцінках німецьких та бельгійських експертів по забрудненню довкілля тільки один корабель забруднює більше, чим кілька мільйонів автомобілів. Міненерго США розроблено проект SF-BREEZE пасажирського порому на 150 чоловік з максимальною швидкістю 35 вузлів. Це судно виконано у вигляді катамарану та відповідає всім вимогам безпеки мореплавання до суден такого типу.

Тож після економічних розрахунків виявилось що його ціна вдвоє дорожче порівняно з аналогами на дизельному паливі. 
18 листопада 2019 року інженерно-конструкторським бюро Норвегіï Vestein Design розроблено судно технологічного призначення, де застосовуються паливні елементи (з протоннообмінними мембранами) фірми Nedstok BV, яке працюватиме лише на водородному паливі.

Водородне паливо зберігатиметься в спеціальних резервуарах під тиском.

Шотландією будується ряд поромів 3 електрорухом 3 терміном здачею в 2021 році чисто на водородному паливі. Перший завод по виробництву «Зеленого» водороду запускається в США уже сьогодні.

На цьому заводі водород будуть отримувати шляхом підігрівання органічних відходів до температури $3870^{\circ} \mathrm{C}$ за допомогою плазмових факелів. Північно-західний університет США отримав матеріали 3 високою пористістю для зберігання водороду та метану.

Корпорація Toshiba Energy Systems побудувала завод для виробництва водороду на базі АС у Фукусіма з продуктивністю $1200 \mathrm{Hм}^{3}$ за годину. Технічний прогрес постійно знаходить нові та більш раціональні технології розщеплення води. Австралійські вчені отримали технологію найбільш ефективного виробництва водороду із води, з використанням залізно-нікелевих каталізаторів, замість рідкоземельних елементів типу рутенію, платини, іридію, які в сотні раз дорожчі.

Kawasaki закінчила будівництво першого в світі танкеру для перевезення водороду в рідиноподібному стані. Вперше дрон зробив повний переліт через атлантичний океан на власному запасі водороду. Отримані нові сонячні елементи для виробництва водороду з рекордною ефективністю.

Футуристична супер'яхта довжиною 111 метрів, працююча на скрапленому водороді представлена на виставці в Монако.

Для використання усіх видів транспорту на водородному паливі необхідно мати інфраструктуру для зберігання, перевезення та бункерних технологій. Вже зараз виготовлення установок для виробництва водороду забезпечують заводи Швейцарії, Германії, Франції, США, Японії та Кореї. В установках використовуються наступні технології:

- Локальна генерація водороду високої чистоти;

- Шляхом водного електролізу;

- Дисоціатори.

1. Процес електролізу водних сумішей солі

$$
2 \mathrm{NaCl}+2 \mathrm{H}_{2} \mathrm{O} \rightarrow 2 \mathrm{NaOH}+\mathrm{CO}_{2}+\mathrm{H}_{2} \uparrow
$$

2. Пропускання водного пару при $1000^{\circ} \mathrm{C}$ над розкаленним коксом 


$$
\mathrm{H}_{2} \mathrm{O}+\mathrm{C} \leftarrow \rightarrow \mathrm{CO} \uparrow+\mathrm{H}_{2} \uparrow
$$

3. Із природного газу (метан)

a) конверсія $з$ паром води

$$
\mathrm{CH}_{4}+\mathrm{H}_{2} \mathrm{O} \leftarrow \rightarrow \mathrm{CO}+3 \mathrm{H}_{2} \text { (при } 1000^{\circ} \mathrm{C} \text { ) }
$$

б) Окиснення киснем з використанням каталізатору

$$
2 \mathrm{CH}_{4}+\mathrm{O}_{2} \leftarrow \rightarrow 2 \mathrm{CO}+4 \mathrm{H}_{2}
$$

Водород можливо отримувати при переробці нафти з концентруванням різноманітних процесів:

- криогенного;

- короткоциклового;

- мембранного.

1. При електролітичній технології

$2 \mathrm{H}_{2} \mathrm{O}=2 \mathrm{H}_{2}+\mathrm{O}_{2}$

водород $є$ досить дорогим продуктом

2. Для отримання із метану

$\mathrm{CH}_{4}=\mathrm{C}+2 \mathrm{H}_{2}$ необхідні високі температури.

В промисловості використовують ряд каталізаторів, які покращують вище приведені технології та роблять їх дешевшими.

Ціни на паливо сьогодні розглядають водночас 3 компенсаціями за забруднення довкілля. Реальним може бути тільки СПГ. Водород не конкурентний для порівняння. Всі види виробництва в судових умовах являються занадто дорогими через електроенергії.

Висновки. Екологічні проблеми та фінансові затрати примушують до пошуків нових рішень у використанні водороду.

Найбільш перспективними для використання водороду, як палива на морському флоті - експлуатація паливних елементів для постійного виробництва водороду на борту судна. Найбільш реальними $\epsilon$ паливні елементи, які використовують СПГ.

Сьогодні із природного газу виробляють:

- 68\% водороду, як чистого продукту;

- 16\% з нафти;

$-11 \%$ з вугілля;

$-5 \%$ з води.

Виробництво водороду з СПГ у 2,5 рази дешевше, ніж при електролізі з води. Та сьогодні СПГ як паливо використовується в усьому світі як основне паливо через відсутність вмісту сірки. 
Сучасні двигуни зможуть бути двопаливними, працювати на СПГ та водороді.

Використання водороду, як палива на морському флоті відповідають всім вимогам безпеки мореплавання. Проте для виконання повністю всіх вимог по запобіганню забруднення довкілля необхідне виробництво «зеленого» водороду.

\title{
Література:
}

1. Шауэнберг Т., Позднякова Н. Рекорд по выбросам CO2: эксперты ООН о реальной угрозе человечеству, 2019. URL: https://p.dw.com/p/3TkAh (дата звернення: 23.09.2020).

2. The world's largest-class hydrogen production, Fukushima Hydrogen Energy Research Field (FH2R) now is completed at Namie town in Fukushima, 2020. URL:https://ecotechnica.com.ua/energy/4749krupnejshij-zavod-po-proizvodstvu-zelenogo-vodoroda-otkryt-vfukusime.html (дата звернення: 23.09.2020).

DOI https://doi.org/10.30525/978-9934-588-79-2-1.44

\section{ВПЛИВ ЗМІННОГО СТУПЕНЯ СТИСНЕННЯ НА ПОКАЗНИКИ РОБОТИ ДВЗ}

\author{
Хоменко В. С. \\ викладач кафедри суднового машинобудування та енергетики \\ Херсонської філії Національного університету кораблебудування \\ імені адмірала Макарова \\ Савчук П. С. \\ студент \\ Херсонської філії Національного університету кораблебудування \\ імені адмірала Макарова \\ м. Херсон, Украӥна
}

В останні роки спостерігається значний прогрес у підвищенні паливної економічності і зниження вмісту токсичних компонентів у відпрацьованих газах автомобільних та суднових двигунів. Провідні двигунобудівні фірми, беручи участь в безперервній гонці за екологічними нормами і борючись за споживача, змушені вдосконалювати 